\title{
PRACTICAL APPLICATION OF CURRENCY SALAM TRANSATION IN ISLAMIC BANKING- A CASE STUDY OF PAKISTAN
}

\author{
Syed Muhammad Hassan Bukhari* \\ Dr. Muhammad Junaid Sharif* \\ Islamic banking with the passage of time is acquiring impetus. \\ Many local and international banks have started to open separate \\ Islamic banking branches and windows to cater the needs of \\ customers who are interested in shari'ah approved products. \\ Islamic banking system is facing a good competition from \\ developed conventional banking system in products and services. \\ With the passage to time the awareness of Islamic banking and \\ its products is improving substantially. The purpose of the \\ study is to understand the practical procedure of currency salam \\ transaction in Islamic banks. Methodology of this paper is \\ quantitative research. For this 60 questionnaires were \\ distributed among bankers dealing in currency exchange \\ transactions in Islamic Banks, out of which 52 respondents were \\ received and used. The content and descriptive analysis \\ techniques were employed to analyze the data. The SPSS software \\ is used to anlayse the data collected by questionnaire. The \\ study supports the literature and according to data almost 71\% \\ respondents of Islamic banks believe that salam transaction is \\ practically implemented in selected Islamic banks. \\ Key words: Currency, Bai, Salam, Contract, Sarf
}

\section{Introduction}

Eradication of riba, gharar and qimar is the first challenge for the establishment of Islamic financial markets. Although Islamic banking has lucratively provided the Islamic models for banking and insurance but research proved that currency markets still needs to be addressed ${ }^{1}$

One of the important task of Islamic banking is to ensure that every transaction between fund provider and user is according to Quranic spirit of Justice and mutual-aid. Islamic banking is considerably an evolving system as compared to any other banking system. Muslims have desire to have such a financial system where the money of savers goes into the hands of investors in such ways which are permitted by the Shariah. Islamic scholars and bankers put their efforts to provide such instruments which are not only according to shariah but also able to pay them halal returns. These scholars are now very successful in their true efforts but still the concepts of Islamic banking and finance are in development stages. Islamic banking and financial institutions have expanded to the global market as the western countries are eager to experiment with Islamic financial techniques.

${ }^{*}$ Lecturer, Virtual University of Pakistan, Lahore..

* Associate Professor, Govt. Islamia College Civil Lines, Lahore. 
To design the various parameters and new products to capture market is a biggest challenge for scholars and practical bankers of Islamic banking.

According to Gupta demand for financial instruments has been increased rapidly. Individuals and organizations are dealing in financial assets such as foreign currencies, bonds, shares and loans. ${ }^{3}$ The prices of these financial assets fluctuate due to market conditions and these fluctuations put dealers on great risk. ${ }^{4}$ To address these types of risks new financial instruments have been introduced in financial markets called financial derivatives. Significance of financial derivatives as tools of risk management are considered less importance as compared to future and option contracts in minimizing risk. ${ }^{5}$ With the use of future and option contracts country party risk is handled up to non-existence. ${ }^{6}$ Derivatives are considered very effective for production planning in agriculture for high volume of trade. With the use of future contracts price could be received in advance and goods delivered on agreed date. ${ }^{7}$ Farmers and millers have a great risk of adverse movements in prices with change in market forces. The only remedy for buyer is to buy the goods in advance at the desired price and keep it in for future time to use it. In this case, the buyer has to incur storage cost and or transportation use to make it available at future date, in the same way the seller can also retain it for buyer for future date for which he adds it in price. ${ }^{8}$ Currency salam can also be used as future contract to facilitate the Islamic product market.

Currency salam is a new product derived from the mechanism of salam transaction not only to address the future market need but also to address risk faced by Islamic financial instruments in financial markets. In this transaction, currency of one country is fully paid in advance to the seller and seller provides the currency of other country on agreed future date to buyer.

\section{Salam}

"Salam is a sale whereby the seller undertakes to supply some specific goods to the buyer at a future date in exchange of an advanced price fully paid at spot ${ }^{\text {", }}$

Islamic legitimacy is derived from the following Quranic verse:

Those who eat riba will not stand (on the Day of Resurrection) except like the standing of a person struck by Satan leading him to insanity. That is because they say: "Trading is only like riba," whereas God has permitted trading and forbidden riba. (Qur'an, $2: 275)$ 
According to Ibn Abbas the above mentioned Quranic Verse (2:282) was revealed to address salam in particular, for in permitting lending, it also permits salam transaction.

Another hadith explained by Ibn Abbas "When God's messenger came to Madina, the people were paying one or two years in advance for fruits, so he said: " Those who pay in advance anything must do for a specified weight and for definite period. ${ }^{10}$

\section{METHODOLOGY}

The research strategy is quantitative and data collected to fulfill the objectives of this research study. In order to address the practical procedure of the product in Islamic banks primary data was collected by survey method by introducing questionnaire. Research design of this study is based on the objectives provided for the research. The research being conducted is the mixed research and is the exploratory study as very few work has been done so preliminary work needs to be done to comprehend the nature of problem. Study setting for this research is Non-contrived, Field study (Minimal interference of the researcher). Unit of analysis is Individual (Books, Shariah advisor, Islamic bankers and books) and the Time horizon is Cross sectional. The target population of the study were bankers and shariah advisors of two selected Islamic Banks of Lahore which are offering currency salam product to their customers.

The data was collected from approximately 50 shariah advisors, Islamic bankers. Judgmental and snow ball sampling techniques were used for sampling the population. The Population is of 20 banks out of which only 3 banks offering this product, so the target population is of 3 bank's shariah advisors and Islamic bankers which are almost 100 . Sample size is taken of $60 \%$ of target population.

The data that was collected for this research was of both primary sources. The Survey design was used for primary data collection in which questionnaire was distributed among the shariah advisors of three selected Islamic Banks of Lahore. According to Saunders, survey is the standard strategy for primary data collection for business research as it intends to collect a significant amount of data from a large sample in cheapest way. ${ }^{11}$

The instrument used for data collection is questionnaire. The questionnaire is based on Dichotomous Scale and guided to investigate the currency salam product with respect to implementation of practical procedure in Islamic Banks. The instrument used was self-created by pilot testing. In data analysis process the data cleaned by eliminating 
unresponsive questions and coding applied. The data analyzed by using SPSS software and different descriptive analysis statistical techniques. From data analysis further recommendations for currency salam product and future prospects for research will be derived.

"Construct validity does not concern the simple, factual question of whether a test measures an attribute. Instead it is about the complex question of whether test score interpretations are consistent with a nomological network involving theoretical and observational terms." 12 To address the validity of instrument used for data collection factor analysis is used. The results are showing communalities extraction that question $2 \& 4$ and question $3 \& 5$ are showing same themes respectively.

Table is showing the results.

\begin{tabular}{|c|c|c|}
\hline & Initial & Extraction \\
\hline $\begin{array}{l}\text { Is currency salam transaction practically implemented as per } \\
\text { shariah standards? }\end{array}$ & 1.000 & .557 \\
\hline $\begin{array}{l}\text { Currency rate used by your bank is the rate derived by the } \\
\text { Government for currency salam transaction. }\end{array}$ & 1.000 & .948 \\
\hline Which date currency rate is being used by your bank? & 1.000 & .540 \\
\hline $\begin{array}{l}\text { If Government rate is not used then which kind of rate is being } \\
\text { used by your bank? }\end{array}$ & 1.000 & .942 \\
\hline
\end{tabular}

Extraction Method: Principal Component Analysis.

It is very important to consider the reliability of the instrument used for gathering data. The cronbach alpha is used to measure the reliability of the instrument. The $88.5 \%$ result shows the significance of questions.

\begin{tabular}{|l|l|c|c|}
\multicolumn{3}{|c|}{ Case Processing Summary } \\
\hline \multirow{3}{*}{ Cases } & Valid & $\mathrm{N}$ & $\%$ \\
\cline { 2 - 4 } & Excluded & 46 & 88.5 \\
\cline { 2 - 4 } & Total & 6 & 11.5 \\
\hline
\end{tabular}

a. List wise deletion based on all variables in the procedure.

Item Statistics

\begin{tabular}{|l|c|c|c|}
\hline & Mean & $\begin{array}{c}\text { Std. } \\
\text { Deviation }\end{array}$ & $\mathrm{N}$ \\
\hline $\begin{array}{l}\text { Is currency salam transaction practically } \\
\text { implemented as per shariah standards? }\end{array}$ & 1.30 & .465 & 46 \\
$\begin{array}{l}\text { Currency rate used by your bank is the rate } \\
\text { derived by the Government for currency salam } \\
\text { transaction. }\end{array}$ & 1.39 & .493 & 46 \\
\hline
\end{tabular}




\begin{tabular}{l|c|c|c|}
\hline $\begin{array}{l}\text { Which date currency rate is being used by your } \\
\text { bank? }\end{array}$ & 1.20 & .401 & 46 \\
$\begin{array}{l}\text { If Government rate is not used then which kind of } \\
\text { rate is being used by your bank? }\end{array}$ & 2.28 & .911 & 46 \\
\hline
\end{tabular}

\section{RESULTS AND DISCUSSIONS}

In line with the objective, the exploratory study was undertaken to get the data by using self-administered questionnaire. The questionnaire was prepared by using dichotomous scale and distributed among those bankers who deals in currency salam transactions of two Islamic banks in the city of Lahore. It was assumed that the respondents would be competent enough to read and understand English, so they could select answers in the questionnaire. For the analysis of data initial analysis techniques were applied by using SPSS 17. The questionnaire is designed to understand that how currency salam transaction is practically implemented in Islamic banks.

The questionnaire contains two main sections. The first one is designed to collect information about the demographic variables of the respondents. The second part is about such constructs which differentiate the practices of both banks to do currency salam transaction. The questionnaire was designed in such a way to avoid biasness.

The target sample size in this study is 60 respondents which is sufficient as only these banks are offering currency salam products in Pakistan. Out of these questionnaires, 52 were returned and usable. The usable response rate was $86 \%$ which is acceptable as per previous studies. $^{13}$

The results depicts that out of these 52 respondents, almost $94 \%$ of the respondents are male, while $6 \%$ of them are female. Furthermore, the age grouping indicates that 67 per cent are between 20 to 30 years old and 33 per cent are between 31 and 40 years old.

With regards to the educational level, 79 per cent are holding a Masters, and 21 per cent are holding an MPhil degree. For the experience status, around 25 per cent of the respondents have less than 2 years of experience, 36 per cent have experience between 2 to 3 years and 39 per cent have experience between 5 to 10 years.

\section{Education}

\begin{tabular}{|l|c|c|c|c|}
\hline & Frequency & Percent & Valid Percent & $\begin{array}{c}\text { Cumulative } \\
\text { Percent }\end{array}$ \\
\hline Valid Mphil & 11 & 21.2 & 21.2 & 21.2 \\
\hline
\end{tabular}




\begin{tabular}{|c|c|c|c|c|c|}
\hline \multicolumn{2}{|c|}{ Epistemology January 2018} & \multicolumn{4}{|c|}{ Practical Application of Currency Salam Transation ... (6) } \\
\hline & Master & 41 & 78.8 & 78.8 & 100.0 \\
\hline & Total & 52 & 100.0 & 100.0 & \\
\hline \multicolumn{6}{|c|}{ Experience in years } \\
\hline & & Frequency & Percent & Valid Percent & $\begin{array}{c}\text { Cumulative } \\
\text { Percent }\end{array}$ \\
\hline \multirow[t]{4}{*}{ Valid } & Less than 2 & 13 & 25.0 & 25.0 & 25.0 \\
\hline & $2-5$ & 19 & 36.5 & 36.5 & 61.5 \\
\hline & $5-10$ & 20 & 38.5 & 38.5 & 100.0 \\
\hline & Total & 52 & 100.0 & 100.0 & \\
\hline \multicolumn{6}{|c|}{ Age in years } \\
\hline & & Frequency & Percent & Valid Percent & $\begin{array}{l}\text { Cumulative } \\
\text { Percent }\end{array}$ \\
\hline \multirow[t]{3}{*}{ Valid } & Up to 30 & 35 & 67.3 & 67.3 & 67.3 \\
\hline & $31-40$ & 17 & 32.7 & 32.7 & 100.0 \\
\hline & Total & 52 & 100.0 & 100.0 & \\
\hline
\end{tabular}

Permissibility of currency salam transaction:

The first question asked by the respondents was is currency salam transaction allowed according to shariah in Table 1 . The results clarify that all respondent found this transaction permissible as 100 percent result figured out.

\section{Table 1}

Is currency salam transaction allowed according to shariah?

\begin{tabular}{|l|c|c|c|c|}
\hline & Frequency & Percent & Valid Percent & $\begin{array}{c}\text { Cumulative } \\
\text { Percent }\end{array}$ \\
\hline Valid Allowed & 52 & 100.0 & 100.0 & 100.0 \\
\hline
\end{tabular}

\section{Practical implementation as per Shariah}

On the second question which was asked by the respondents that is currency salam transaction practically implemented as per shariah $71 \%$ respondents agreed that it is as per shariah.and almost 29 per cent respondents response was in disagreement. From the result it could be derived that training of bankers required extency training to understand the practical procedure as per shariah.

\section{Table 2}

Is currency salam transaction practically implemented as per shariah standards?

\begin{tabular}{|l|l|l|l|l|}
\hline & Frequency & Percent & Valid Percent & Cumulative Percent \\
\hline
\end{tabular}




\begin{tabular}{|c|c|c|c|c|}
\hline Valid Yes & 37 & 71.2 & 71.2 & 71.2 \\
No & 15 & 28.8 & 28.8 & 100.0 \\
Total & 52 & 100.0 & 100.0 & \\
\hline
\end{tabular}

\section{Currency rate applied for transaction}

Table 3 shows that 81 per cent of respondents agreed that the rate which is used for the currency salam transaction is date of delivery.

\section{Table 3}

Which date currency rate is being used by your bank?

\begin{tabular}{|c|c|c|c|c|c|}
\hline & & Frequency & Percent & Valid Percent & $\begin{array}{l}\text { Cumulative } \\
\text { Percent }\end{array}$ \\
\hline \multirow[t]{3}{*}{ Valid } & $\begin{array}{l}\text { Date of } \\
\text { Transaction }\end{array}$ & 42 & 80.8 & 80.8 & 80.8 \\
\hline & Date of Delivery & 10 & 19.2 & 19.2 & 100.0 \\
\hline & Total & 52 & 100.0 & 100.0 & \\
\hline
\end{tabular}

Rate used for transaction is of Government rate

The results of Table 4 shows that $61 \%$ of respondents do agree that currency rate used for the currency salam transaction is the rate which provided by Government.

\section{Table 4}

Currency rate used by your bank is the rate derived by the Government for currency salam transaction.

\begin{tabular}{|ll|c|c|c|c|}
\hline & & Frequency & Percent & Valid Percent & Cumulative Percent \\
\hline Valid & Yes & 32 & 61.5 & 61.5 & 61.5 \\
& No & 20 & 38.5 & 38.5 & 100.0 \\
& Total & 52 & 100.0 & 100.0 & \\
\hline
\end{tabular}

\section{Rate used other than government rate}

Table 5 shows that for currency salam transacton internal driven rate of bank is used.

\section{Table 5}

If Government rate is not used then which kind of rate is being used by your bank?

\begin{tabular}{|ll|c|c|c|l|}
\hline & & & & Cumulative \\
& & Frequency & Percent & Valid Percent & Percent \\
\hline Valid & Internal Driven & 16 & 30.8 & 30.8 & 30.8 \\
& Mutual Agreed & 5 & 9.6 & 9.6 & 40.4 \\
& Not Applicable & 31 & 59.6 & 59.6 & 100.0
\end{tabular}


If Government rate is not used then which kind of rate is being used by your bank?

\begin{tabular}{|ll|c|c|c|l|}
\hline & & & & $\begin{array}{l}\text { Cumulative } \\
\text { Percent }\end{array}$ \\
\hline Valid & Internal Driven & 16 & 30.8 & 30.8 & 30.8 \\
& Mutual Agreed & 5 & 9.6 & 9.6 & 40.4 \\
& Not Applicable & 31 & 59.6 & 59.6 & 100.0 \\
Total & 52 & 100.0 & 100.0 & \\
\hline
\end{tabular}

\section{Conclusion and recommendations}

The practical implementation of currency salam transactions in Islamic banks is explored. The questionnaire properly address the main ingredients and analyse the practical procedure and implementation of currency salam transaction in Islamic banks.

After the above thorough discussion and research results shows that $100 \%$ respondents agree that salam transaction is allowed in Islam and $71 \%$ are agreed that it is practically implemented in their bank as per shariah guidelines.

This is pioneer study conducted in Lahore regarding the salam transaction in currencies. Although it is a pioneer study but it has some limitations. Firstly the questionnaire is used as a data collection tool so it is expected that biasness factor may affect the research and make it less generalized. Secondly that data is collected from the three Islamic banks of Lahore only. The reason is this only these three banks are offering currency salam product in Pakistan. That's why it was very difficult to increase the number of respondents to make the study more intensive.

The findings have sound implications for the body of knowledge, the practitioners, stakeholders and specially to policy makers of shariah boards who can analyze that is the practical procedure of currency salam transaction is as per shariah rules. The results enrich the literature to practically understand the procedures and practical hurdles found to comply with shariah jurisdiction.

Hence, the future studies are recommended firstly to take shariah scholars point of view on the procedure of currency salam transaction provided by the bankers, secondly it should be extended to other banks of different countries as well. For instance, there are efforts that have been done by other banks to initialize currency salam 
transactions in their banks as it is good product to capture the entire currency market.

\section{REFERENCE \& NOTES}

1 Obaidullah, Mohammed. "Financial Contracting in Currency Markets: An Islamic Evaluation.,.." International Journal of Islamic Financial Services 3, no. 3 (2001).

2 Iqbal, Munawar, Aușāf Aḥmad, and Tariqullah Khan. Challenges Facing Islamic Banking. Islamic Development Bank, Islamic Research and Training Institute, 1998.

${ }^{3}$ Gupta, SL. Financial Derivatives: Theory, Concepts and Problems. PHI Learning Pvt. Ltd., 2005.

${ }^{4}$ Kevin, S. Security Analysis and Portfolio Management. PHI Learning Pvt. Ltd., 2008.

5 Al-Amine, Muhammad al-Bashir. "Commodity Derivatives: An Islamic Analysis." New York: Palgrave Macmillan, 2005.

${ }^{6}$ Gurusamy, Dr S. "Financial Services and Markets." (2004).

7 Kamali, Mohammad Hashim. "Islamic Commercial Law: An Analysis of Futures." American Journal of Islamic Social Sciences 13, no. 2 (1996): 197-224.

${ }^{8}$ Ehsan, Muhammad. "Islamic Perspective on Financial Derivatives: Demand for Instruments of Risk Management in Various Businesses of Pakistan." Durham University, 2012.

${ }^{9}$ Usmani, Justice Taqi. An Introduction to Islamic Finance. Karachi: Idara Isha'at e Diniyat, 1998.

${ }^{10}$ Al Zaabi, Obaid Sai. "Salam Contract in Islamic Law: A Survey." (2011).

11 Saunders, Chad, and Mike Chiasson. "Using Knowledge Management Systems to Structure Knowledgeable Practices." Paper presented at the System Sciences, 2009. HICSS'09. 42nd Hawaii International Conference on, 2009.

${ }^{12}$ Cronbach, Lee Joseph. "Construct Validity in Psychological Tests, Psychological Bulletin." In, no. 52 (1955): 281-302.

13 Metawa, Saad A, and Mohammed Almossawi. "Banking Behavior of Islamic Bank Customers: Perspectives and Implications." International Journal of Bank Marketing 16, no. 7 (1998): 299313. 